$$
02-881
$$
July 8, 1974

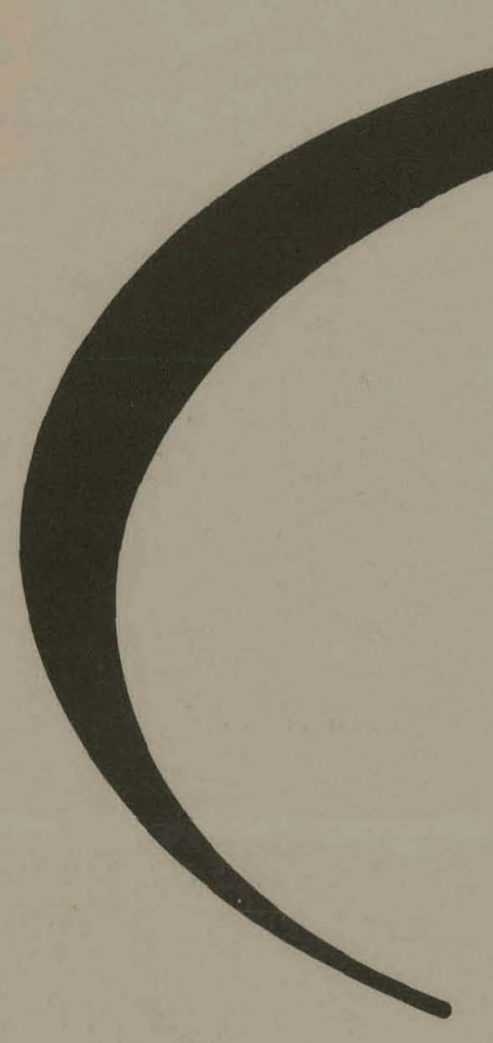

\title{
CHEMICAL MILLING OF BERYLLIUM \\ FOR MACHINING DAMAGE REMOVAL
}

Robert L. Riegel

Everett L. Childs

Kenneth R. Souply

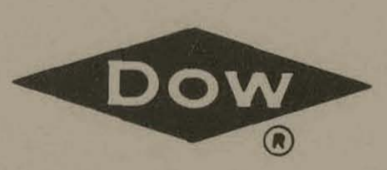

DOW CHEMICAL U.S.A. ROCKY FLATS DIVISION

P. O. BOX 888

GOLDEN, COLORADO 80401

U.S. ATOMIC ENERGY COMMISSION

CONTRACT AT(29-1)-1106 


\section{DISCLAIMER}

This report was prepared as an account of work sponsored by an agency of the United States Government. Neither the United States Government nor any agency Thereof, nor any of their employees, makes any warranty, express or implied, or assumes any legal liability or responsibility for the accuracy, completeness, or usefulness of any information, apparatus, product, or process disclosed, or represents that its use would not infringe privately owned rights. Reference herein to any specific commercial product, process, or service by trade name, trademark, manufacturer, or otherwise does not necessarily constitute or imply its endorsement, recommendation, or favoring by the United States Government or any agency thereof. The views and opinions of authors expressed herein do not necessarily state or reflect those of the United States Government or any agency thereof. 


\section{DISCLAIMER}

Portions of this document may be illegible in electronic image products. Images are produced from the best available original document. 


\section{LEGAL NOTICE}

This report was prepared as an account of work sponsored by the United States Government. Neither the United States nor the United States Atomic Energy Commission, nor any of their employees, nor any of their contractors, subcontractors, or their employees, makes any warranty, expressed or implied, or assumes any legal liability or responsibility for the accuracy, completeness or usefulness of any information, apparatus, product or process disclused, or represents that its use would not infringe privately owned rights.

Printed in the United States of America

Available from the

National Technical Information Service

U. S. Department of Commerce

Springfield, Virginia 22151

Price: Printed Copy $\$ 4.00$ Microfiche $\$ 1.45$ 


\title{
CHEMICAL MILLING OF BERYLLIUM FOR MACHINING DAMAGE REMOVAL
}

\author{
Robert L. Riegel \\ Everett L. Childs \\ Kenneth R. Souply
}

Chemistry, Research and Development

CHEMICAL TECHNOLOGY GROUP
This report was prepared as an account of work sponsored by the United States Government. Neither the United States nor the United States Atomic Energy Cominission, nor any of their employees, nor any of Commission, nor any of their employees, nor any of theis contractors, subcontractors, or their employees, makes any warranty, express or implien, or assumes any legal liability or responsibility for the accuracy, com- pleteness or usefulness of any information, apparatus, product or process disclosed, or represents that its use would not infringe privately owned rights.

DOW CHEMICAL U.S.A. ROCKY FLATS DIVISION

P. O. BOX 888 GOLDEN, COLORADO 80401

Prepared under Contract AT(29-1)-1106

for the

Albuquerque Operations Office

- U.S. Atomic Energy Commission

\section{Beryllium}

Chemical Milling 
RFP-2174 


\section{CONTENTS}

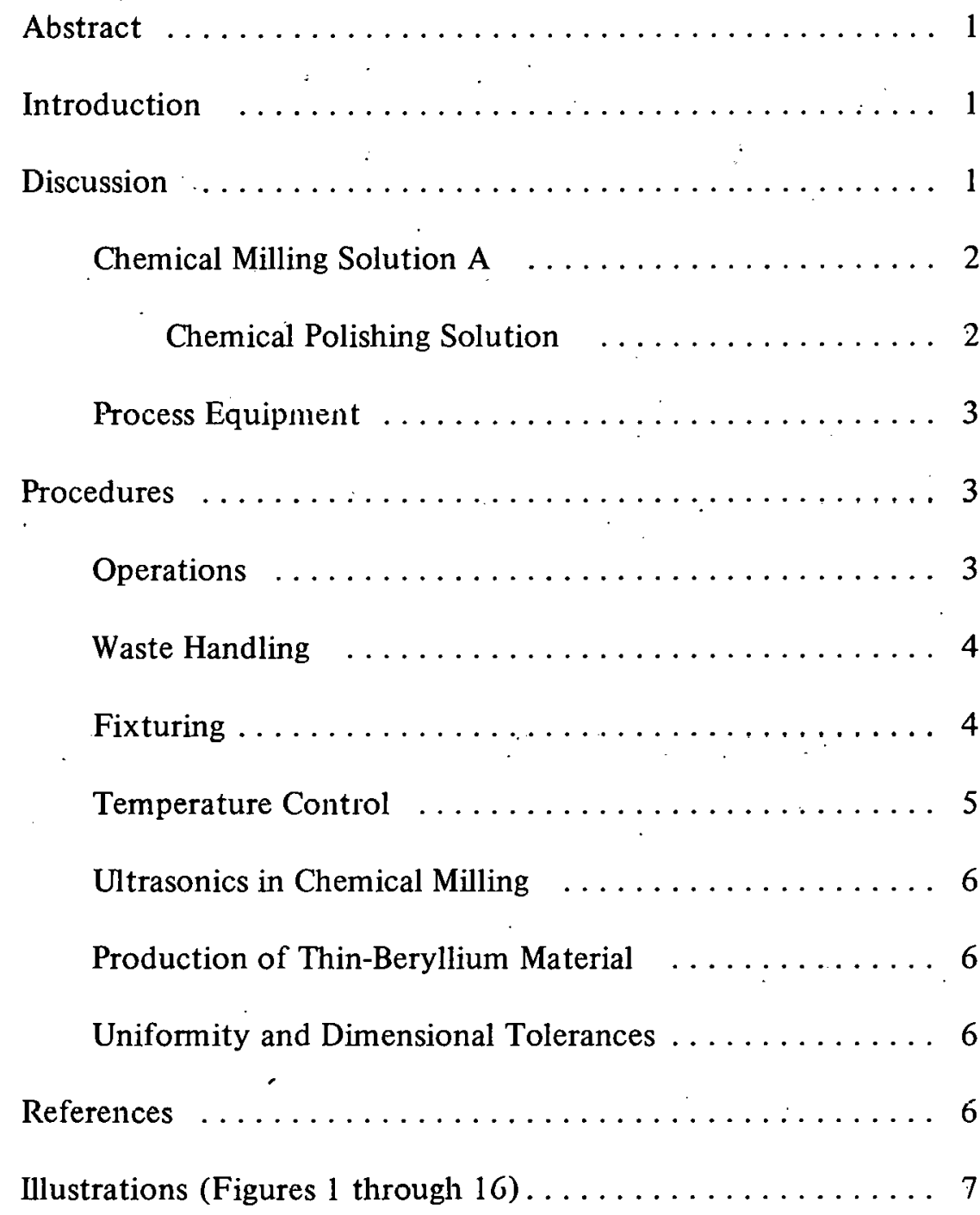




\section{A C K N O W L E D G M E N T S}

The authors wish to acknowledge Charles E. Wickland of Metallurgy Operations and his group, for suggestions and efforts in the implementation of the described process. Dennis R. Floyd of the General Metallurgy Group is acknowledged for technical assistance, and thanks is expressed to Edward Vejvoda of Chemical Technology and Alan K. Williams of the Chemical Operations Group for their encouragement and guidance. 


\title{
CHEMICAL MILLING OF BERYLLIUM FOR MACHINING DAMAGE REMOVAL
}

\author{
Robert L. Riegel, Everett L. Childs, and Kenneth R. Souply
}

\begin{abstract}
A chemical milling process for removal of machining damage from beryllium was developed and implemented. Details are given of a chemical milling solution prepared especially for ingot-source beryllium to meet surface finish specifications. The solution is used in the production of both ingot-source and powder-source beryllium parts. Close dimensional tolerances and improved uniformity were-achieved by using temperature control and by rotary fixturing. A new concept for fixturing was developed which utilizes the buoyancy of beryllium parts in the milling solution to position and rotate the parts during the chemical milling operation.
\end{abstract}

\section{INTRODUCTION}

Chemical milling produces intricate shapes or designs in metals and removes gross quantities of unwanted material. The process is used mostly in circuit panel manufacturing, photoengraving, and weight control for space vehicle and aircraft components. It provides a method to perform tasks not possible by conventional techniques and is less expensive than other methods in completing simple tasks.

When working with beryllium, chemical milling is used also to produce parts with greater strength and ductility than those prepared by conventional machining methods. Although annealling of a part after fabrication achieves the same results, it also causes dimensional distortion (1). ${ }^{1}$ Chemical milling is used to remove superficial microscopic damage caused by conventional machining procedures extending to a depth of one to several thousandths of an inch (mils). [For SI (metric) use: $1 \mathrm{mil}=2.54 \times 10^{-5}$ metres and $1 \mathrm{inch}=25.4$ millimetres.] The damage consists of microcracks about 0.1-mil deep and twinning of surface and subsurface grains (2). Extensive studies have shown that beryllium fractures initiate in twinned

\footnotetext{
${ }^{1}$ Numerals in parentheses relate to references at end of text.
}

regions and propagate along twin-matrix interfaces (3). Twinning in beryllium has been described by several authors $(2,3,4,5,6)$. Their work and efforts at Rocky Flats $(1,7)$ have shown that removal of the microcracks and twinned grains by chemical methods improves the strength and ductility of the beryllium.

Beryllium with the high strength and ductility achieved by chemical milling was required for certain programs at Rocky Flats. Ingot-sheet beryllium (1), as well as powder-source beryllium was specified. Removal was required of at least 4 mils per surface on ingot-source beryllium (1) and of 2 mils per surface on powder-source beryllium (8).

Beryllium ingot-sheet fabrication technology, such as casting, rolling, forming, joining, machining etc., was developed at Rocky Flats. The principal advantages of ingot-sheet include potentially lower cost, excellent formability, and good weldability. Its main disadvantages as compared to powder source are lower yield strength and lack of soundness in sheets thicker than 0.350 inches (1).

This report describes: (a) The chemical milling process at Rocky Flats, (b) The development work done with fixturing to achieve uniformity and surface finish, and (c) A solution suitable for both ingot- and powder-source beryllium.

\section{DISCUSSION}

Problems relating to the use of ingot-source beryllium included rough surfaces, nonuniformity of material removal, control of milling rates, impractical milling rates, inadequate fixturing, pitting, cratering, smut formation, and corrosion of equipment. Solutions used by various authors for powder-source beryllium were not satisfactory for work with ingot-source beryllium (see References 1 through 10). Thus the first step was to 
prepare a suitable solution for use in the chemical milling process.

Special fixturing was needed to prevent undesirable marks on the parts and promote uniformity. Parts that were chemical-milled on every surface simultaneously left no place for a fixture to grasp. If the parts could be rotated during the chemical milling process, greater uniformity could be achieved.

\section{Chemical Milling Solution A:}

It was planned to develop a solution, similar to other phosphoric, chromic, sulfuric, and water solutions used on beryllium by several investigators $(4,9$, and 10$)$. Surface finish was used as the criterion and machined ingot-source beryllium as the subject material. The Chemical Milling Solution A, finally achieved for machined ingotsource beryllium, can also be used in working with powder-source beryllium (see Table I).

The initial experimental Solution B consisted of:

790 millilitres per litre $(\mathrm{ml} / \mathrm{l})$ of phosphoric acid $\left(\mathrm{H}_{3} \mathrm{PO}_{4}\right)$

73.5 grams per litre $(\mathrm{g} / \mathrm{l})$ of chromic trioxide $\left(\mathrm{CrO}_{3}\right)$

$31.5 \mathrm{ml} / 1$ of sulfuric acid $\left(\mathrm{H}_{2} \mathrm{SO}_{4}\right)$

$160 \mathrm{ml} / \mathrm{l}$ of water $\left(\mathrm{H}_{2} \mathrm{O}\right)$

Preliminary experimentation with the solution showed a surface-finish change with the addition of about 5 percent more of any ingredient. The concentration of each acid was then varied while holding the concentration of the other two acids constant. Water was used to maintain constant volume, so that the other acid concentrations would remain constant also. Surface finish was plotted against concentration in each case. The experiment was then repeated using the new near-optimum concentrations and approximately one percent variations.

The above research led to development of the optimum solution given in Table I. Variations in concentrations within the limits stated in Table I were found to produce immeasurably small changes in the surface finish.
TABLE I. Chemical Milling Solution A.

$750( \pm 15)$ millilitres per litre of phosphoric acid $\left(\mathrm{H}_{3} \mathrm{PO}_{4}\right)$ ( 85 percent)

71 ( \pm 2$)$ grams per litre of chromic acid $\left(\mathrm{CrO}_{3}\right)$ ( 99 percent chromic trioxide)

$( \pm 5)$ millilitres per litre of water $\left(\mathrm{H}_{2} \mathrm{O}\right.$ ) (distilled or deionized)

( \pm 2) millilitres per litre of sulfuric acid $\left(\mathrm{H}_{2} \mathrm{SO}_{4}\right)$ (95 to 98 percent)

$$
\begin{aligned}
\text { Temperature: } & 70^{\circ} \mathrm{C}( \pm 2) \\
\text { Rate: } & 0.3 \text { mils per minute from each surface } \\
\text { Specific Gravity: } & \text { At } 25^{\circ} \mathrm{C}=1.598 \\
& \text { At } 70^{\circ} \mathrm{C}=1.560 \\
\text { Enthalpy: } & -119.8( \pm 6.8) \text { kilocalories per mole } \\
& \text { (for beryllium) } \\
& \begin{array}{l}
-107.3( \pm 1.3) \text { kilocalories per mole } \\
\text { (used solution) }
\end{array}
\end{aligned}
$$

\section{Chemical Polishing Solution}

Before development of the Chemical Milling Solution A, a polishing solution to improve the surface finish of ingot-source beryllium was developed using the same method as described for Solution A. Phosphoric, sulfuric, and nitric acids and water were used. The formula and operating temperature are noted in Table II. The best finish produced with this solution on ingot-source beryllium was 15 microinches per inch $(\mu \mathrm{in} / \mathrm{in})$. The finish depended on the grain size, the amount of material removed, and the size of the part or sample being polished. The surface finish improved as the sample or part and grain size decreased, and the amount of removed material (to a limit) increased. The polishing solution did not remove material uniformly. If more than 0.0015 inches were removed, dimensional uniformity tolerances could not be met: Removal of 0.0015 inches from the part improved the finish from about $180 \mu \mathrm{in} /$ in to better than $125 \mu \mathrm{in} / \mathrm{in}$.

The polishing solution was being used in the production process prior to implementation of the 
TABLE II. Chemical Polishing Solution (nominal concentrations).

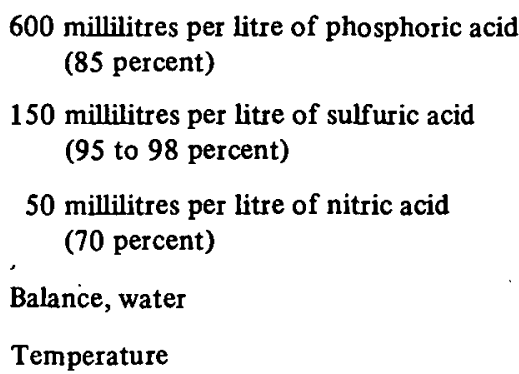

$\left(\mathrm{H}_{3} \mathrm{PO}_{4}\right)$

$\left(\mathrm{H}_{2} \mathrm{SO}_{4}\right)$

$\left(\mathrm{HNO}_{3}\right)$

$\left(\mathrm{H}_{2} \mathrm{O}\right)$

$100{ }^{\circ} \mathrm{C}( \pm 5)$
Chemical Milling Solution A. It followed use of Chemical Milling Solution B. When the new solution (A) given in Table I was implemented, the chemical polishing step was no longer needed.

\section{Process Equipment:}

The chemical milling tanks are installed in hoods to control the environment of the working areas (see Figures 1, 2, and 3). ${ }^{2}$ The hood exhaust passes through a scrubber for control of effluents to the outside atmosphere. A 36.5 by 20.5 by 24-inch tank and a sink ( 19 by 16 by 10 inches) used for a rinse tank are both located in one hood (Figure 1). Three smaller tanks ( 17.5 by 15.5 by 12 inches) and two sinks are located in a separate hood (see Figure 2). All tanks are installed at bench level. The hood and tank construction consists of stainless steel and the scrubber and ductwork of Fiberglas reinforced polyester (FRP).

Fine temperature control is accomplished in the larger tank by regulating cooling-water flow with a throttle valve operated by an indicating pneumatic controller. Three 2000-watt quart.7 heaters provide the necessary heat. A seven-day timer turns the heat on each working day to save start-up time.

Temperature control in the smaller tanks is accomplished by operating cooling-water solenoid valves and heater relays with an indicating dualcircuit electric controller. The heaters are 1000watt quartz. A seven-day timer is in each heater circuit.

\footnotetext{
${ }^{2}$ Figures are included at end of text, beginning on Page 7.
}

A motorized rotary fixture (Figures 4, 5, 6, and 7) in the large tank runs all production parts presently manufactured and many special order parts. Four simple adjustments are required to set up for different part types. A stationary fixture (Figures 8 and 9 ) is provided at each of the smaller tanks. Cooling coils are provided for temperature control inside certain parts when stationary fixturing is used.

\section{PROCEDURES}

\section{Operations:}

The solution is prepared in a 200-gallon, open-top tank, pumped into an elevated storage tank, and transferred by gravity as needed to work tanks (see Figure 3). An additional tank of solution is made up by the operator before the first storage tank becomes empty.

The chemical milling tanks are filled with solution at the end of each day for the following day's work. The solution level is adjusted to allow two inches between the part and the bottom of the tank, as the part is immersed one-half inch below the surface. (See Figure 3.)

Timers turn on heaters and agitators before the start of each day's work shift. At the start of the shift, the working solutions are at the $70^{\circ} \mathrm{C}$ operating temperature.

Using deionized water, the specific gravity of the chemical milling solution is adjusted to 1.560 (at $70^{\circ} \mathrm{C}$ ), before starting the milling operation.

A temperature reading is taken after the gravity adjustment. Fixtures are changed or adjusted to run the part types scheduled for chemical milling. On the motorized rotary fixture (Figures 7 and 10), the roller arms are lengthened or shortened to match the part diameter and locked in place with thumb screws. Similarly, the drive wheel and idler wheel shafts are lengthened or shortened depending on the part height. The stationary fixtures must be changed to run different part types because each fixture is designed for one part type only.

The chemical milling operation begins by simply immersing the part in the tank of hot solution. 
When the reaction starts, the part floats. The buoyant force is utilized to cradle the part in the fixture. As the part is held with a pair of tongs in one hand of the operator, the fixture is lowered onto the part with the other hand (Figure 5).

On the motorized fixture, the part is guided with the tongs against the rollers and wheels (Figures 6 and 7). It is then turned loose and watched momentarily. The idler wheel will turn if the part has been situated properly and is rotating.

On each stationary fixture, the part is held so the rim goes into the $V$-shaped guides (Figure 8 ). The fixture is then locked into position so the part remains immersed about one-half inch below the solution surface (Figure 9). Using tongs, the part is then rotated manually every 15 to 30 seconds. The stationary fixtures are used only when the motorized fixture cannot handle the entire production load.

The amount of metal removed is controlled by timing the operation. A timer starts as the part is first immersed in the solution. The chemical milling time is determined by computation, using the milling rate in Table I. The time is varied with experience.

The parts are rinsed with water immediately after removal from the milling solution to prevent staining. After a tank rinse, parts are given a hot, running tap-water rinse to ensure that no milling solution remains on them. Some parts, which require subsequent welding, are dipped in a solution of sodium bicarbonate to neutralize all traces of residual acid.

\section{Waste Handling:}

When a tank of chemical milling solution is spent, it is gravity-transferred to a 35-gallon sump. A float level control turns on a pump when the sump is.full, and the solution moves to a portable 500-gallon dumpster (see Figure 1). The dumpster is hauled to the waste disposal facility where the solution can be diluted with other waste streams

- and neutralized before undergoing filtration and evaporation. [For SI (metric) use: 1 gallon (liquid) $=3.785$ litres.]

\section{Fixturing:}

The motorized rotary fixture (Figures $4,5,6$, and 7) is designed around the concept of utilizing the flotation of thin beryllium parts in the chemical milling solution. Beryllium, in thinwall configurations, floats while being chemicalmilled, because the reaction gassing lends it buoyancy, even though its density (1.85) is greater than that of the solution (1.56). A beryllium object will float in the chemical milling solution at $70^{\circ} \mathrm{C}$ if its surface area-toweight ratio is 2 square centimetres per gram $\left(\mathrm{cm}^{2} / \mathrm{g}\right)$ or greater.

The motorized fixture is considered automatic since it requires no attention from the time of loading to when the part has been tinished. The drive wheel and idler wheel are visible above the surface of the solution (Figure 4), and a quick glance at the idler wheel ascertains whether the wheel turns and that the part is rotating properly.

The rotating fixture runs all production parts on hand, and many special order parts. Only four simple adjustments are required to change from one part type to another. The rather large thumb screws, clearly visible in Figures 7 and 10, are loosened and the arms and shafts are lengthened or shortened so the part fits against the rollers and wheels properly. For one part type, the slotted ring shown in Figures 6 and 7, the rollers: have to be aligned in the same plane. This is accomplished by holding a part against the rollers and turning the arms so all rollers contact the rim of the part.

Rotating fixture development started with design and construction of a pilot fixture shown in Figures 11 and 12. The device was designed to rotate two different part types; and studies of the fixture in operation led to the design of the present fixture. The most important improvement was elimination of drive-wheel slippage by using an upper wheel to drive the part. The buoyancy of 
the part exerts a greater force against the upper wheels. Another significant improvement was reorientation of the arms for greater versatility.

At first, on the pilot and production model fixtures, single rollers were used to ride the rim of the parts (Figures 11,12, and 13), but they were not satisfactory for use with the slotted ring. Polyethylene rider blocks (Figure 14) allowed rotation of the slotted ring, but the friction between the blocks' surface and the rims of other parts was too great. Teflon ${ }^{\circledR}$ blocks were tried in an attempt to reduce friction, but the results were not satisfactory. They did not work because Teflon rubbed off onto the part rim and prevented milling in spots. Polypropylene cracks in the milling solution.

The double-roller assemblies shown in Figures 6 and 7 allow rotation of all present production parts and many special order parts. They simplify further the change from one part type to another. They take the place of the single rollers and rider blocks, but are never exchanged for anything else.

Stationary fixturing, utilizing the beryllium-part buoyancy as does the rotary fixturing, was used initially and still exists as a back-up to the rotary fixturing. The stationary fixture design is shown in Figures 8 and 9. The fixtures did not grasp the parts. The buoyant force caused the parts to float upward and their rims to fit into the V-shaped guides on the fixtures (Figures 8 and 9). The $\mathrm{V}$-shaped guides also provided centering for a cooling coil for temperature control inside certain parts (discussed in the next section).

The process using stationary fixturing required almost continuous operator attention for frequent repositioning of the workpiece to prevent serious grooving at the fixture contact points. Even with periodical repositioning of the parts, undesirable marks were left at the fixture contact points. Two theories were used to explain the grooving phenomenon. First, galvanic action was probably responsible for most of the grooving with metallic fixtures since beryllium is less noble than the metals used. Secondly, solution trapped or in a corner so its heat of reaction was not readily dispersed, reacted faster because of its higher temperature. The second theory was considered because plastic contact points did not completely eliminate the grooving.

Other types of fixturing tried were totally unacceptable because of the grooving and other types of marking.

\section{Temperature Control:}

Temperature control is important to attain a constant milling rate so dimensional tolerances can be met. With the close temperature control used during the chemical milling process, parts can usually be run by time without an interim dimensional inspection.

Heating and cooling are required because the bath operates at an elevated temperature, and the chemical milling reaction is exothermic. The enthalpy of the reaction has been determined (11) and is given in Table I.

Temperature control was required inside certain parts when the stationary fixturing was used. With the centerline oriented vertically, the solution could not circulate freely between the inside and outside of certain parts, such as the one shown in Figure 15. The temperature would rise as much as $10^{\circ} \mathrm{C}$ inside the parts.

A cooling coil provided the necessary temperature adjustment inside these parts. The coil design is illustrated in Figure 16. The coil for one part type was 5 turns of stainless tubing $(3 / 8)$ in a 2 -inch diameter coil, while another was 3.5 turns of tubing $(5 / 16)$. The polyethylene baffle plate forces the solution to flow nearer to the surface of the coils for more efficient, more uniform cooling. The solution flow was caused by the reaction gassing. The flow was therefore in an upward direction at the part walls and in a downward direction at the center, where the coil was located.

The rotary fixturing orients the part centerline nearly horizontal; the solution can circulate inside and out, and temperature control inside the part is not required. 


\section{Ultrasonics in Chemical Milling:}

High intensity ultrasonics ( 5 watts per square inch) was found to greatly improve the chemical milling uniformity in the process, prior to employment of the Chemical Milling Solution A. The new solution was found to chemical mill within specifications without using ultrasonics. The difference probably resulted from the difference in viscosity between the two solutions. The old solution (B) was more viscous and ordinary methods of agitation may not have been effective. Sound waves agitated the solution by cavitation at the surface of the part; therefore, the agitation was more uniform from one surface point to another.

\section{Production of Thin-Beryllium Material:}

To demonstrate the integrity of the chemical milling system, parts were chemical-milled from a 0.050-inch, starting-wall thickness down to 0.005 inches with less than 0.001 -inch variation. Parts with 0.002 -inch thick walls have been produced, but pin holes were present in thicknesses less than 0.005 inches.

\section{Uniformity and Dimensional Tolerances:}

Uniformity problems have been almost eliminated by the rotary fixturing and the use of the special Chemical Milling Solution A. When the chemical milling solution is fresh, the parts are milled uniformly. As the solution is used, the milling characteristics change gradually and more material is removed in some areas than in others. This phenomenon has not been explained, but has been met partially by milling parts with tight tolerances in fresh solution until the tolerance limits are approached, then moving on to parts with less stringent tolerances, and eventually discarding the solution. Dimensional tolerances of \pm 0.0015 inches are consistently met using the chemical milling process and removing as much as 0.014 inches of material. Closer tolerances can be held as demonstrated by the thin-material production reported above. Tolerances of \pm 0.0005 inches on small parts should not be difficult to hold for machining damage removal, providing machining tolerances are comparable.

\section{REFERENCES}

1. Dennis R. Floyd of Rocky Flats. Private Communication. January 24, 1973; January 4, 1972; April 12, 1971; and February 8, 1968.

2. Henry H. Hausner. Beryllium: Its Metallurgy and Properties. University of California Press, Berkeley and Los Angeles, California. 1965.

3. M. I. Jacobson, F. M. Almeter, and E. C. Burke. "Surface Damage in Beryllium." Transactions of the American Society for Metals 55:492. 1962.

4. D. W. White, Jr: and J. E. Burke. The Metal Bcryllium. American Society for Metals, Cleveland, Ohio. 1955.

5. G. E. Darwin and J. A. Buddery. Beryllium. Butterworths Scientific Publications, London, England. 1960.

6. H. D. Hanes, S. W. Porembka, J. B. Melehan and P. J. Gripshover. Physical Metallurgy of Beryllium. DMIC Report 230. Battelle Memorial Institute, Columbus, Ohio. June 24, 1966.

7. Stanley Beitscher of Rocky Flats. Private Communication. April 12, 1971.

8. Materials Advisory Board. Evaluation Test Methods for Beryllium. MAB-205-M. National Academy of Sciences, National Research Council, Washington, D. C. March 1966.

9. R. F. Williams and S. E. Ingels. The Fabrication of Beryllium. Metal Removal Techniques. Volume III. NASA TM X-53453. George C. Marshal Space Flight Center, Huntsville, Alabama. August 1966.

10. L. Missel and M. E. Shaheen. "Chemical Milling of Beryllium." Metal Finishing 63:59. November 1965.

11. James D. Navratil and Franklin L. Oetting. The Heats of Solution of Beryllium in Chemical Milling Solutions. USAEC RFP-1985. Rocky Flats Division, Dow Chemical U.S.A., Golden, Colorado. January 24, 1973. 


\section{ILLUSTRATIONS}

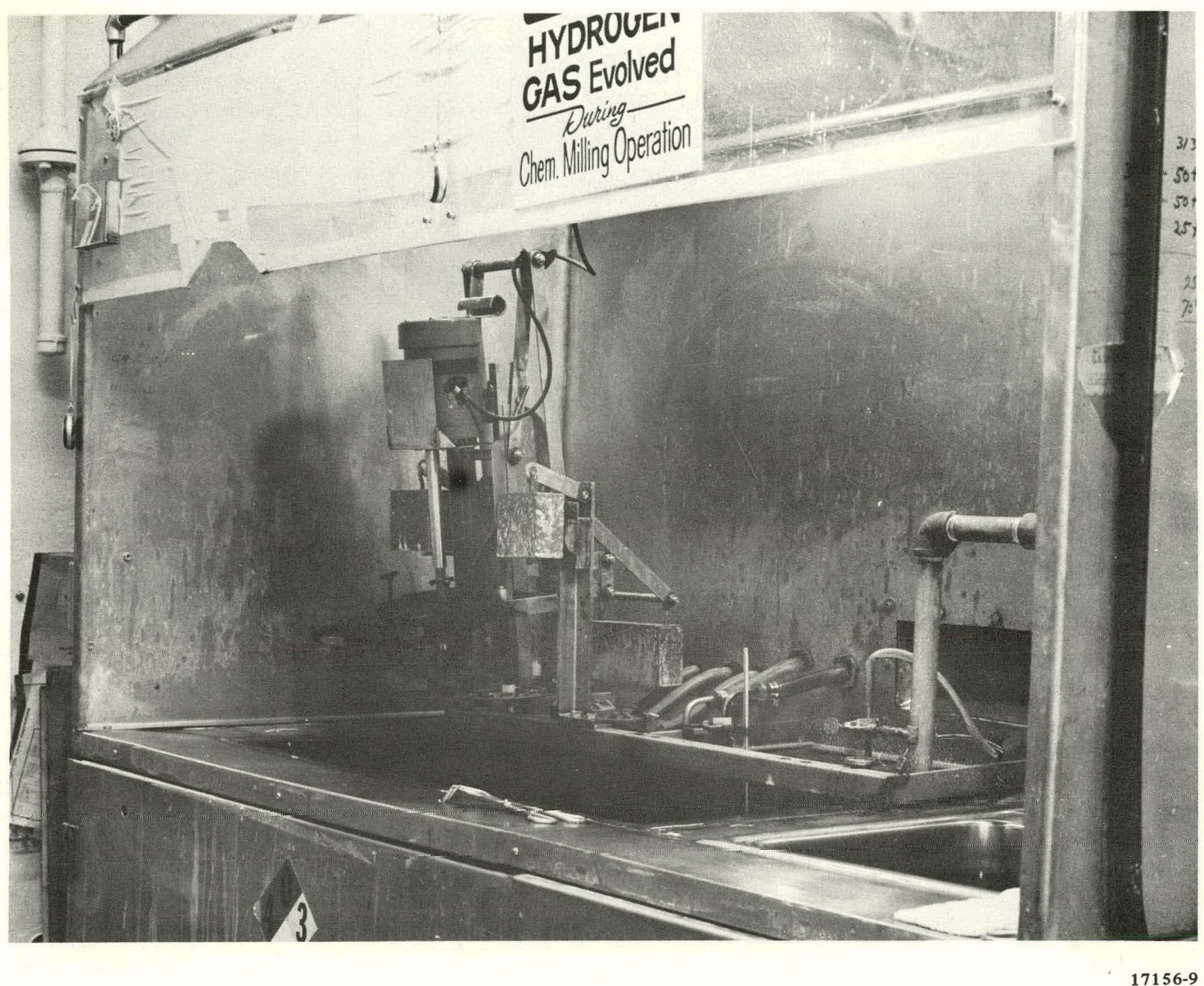

FIGURE 1. Chemical Milling Process Tank and Hood. 


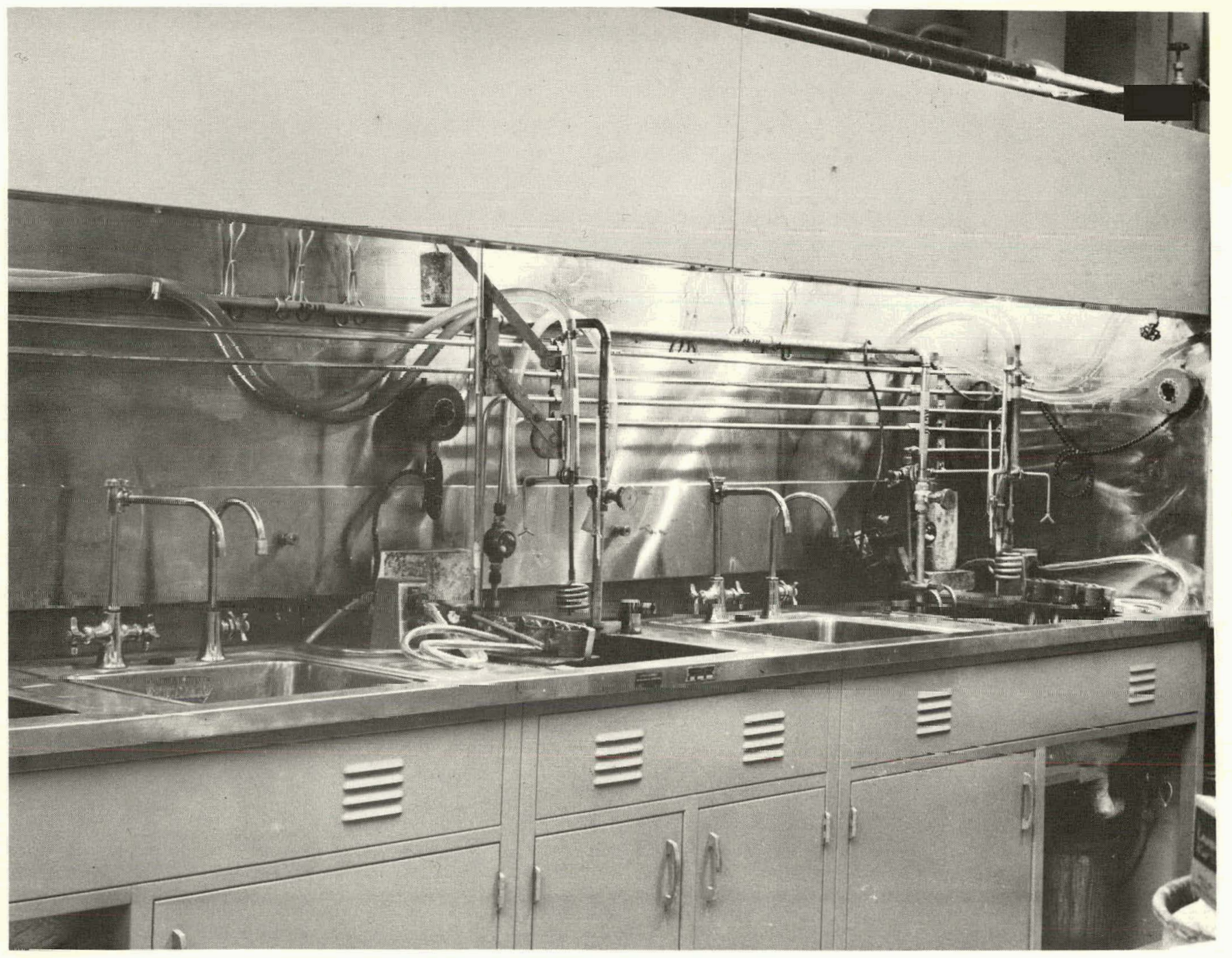

FIGURE 2. Auxiliary Chemical Milling Tanks and Hood. 


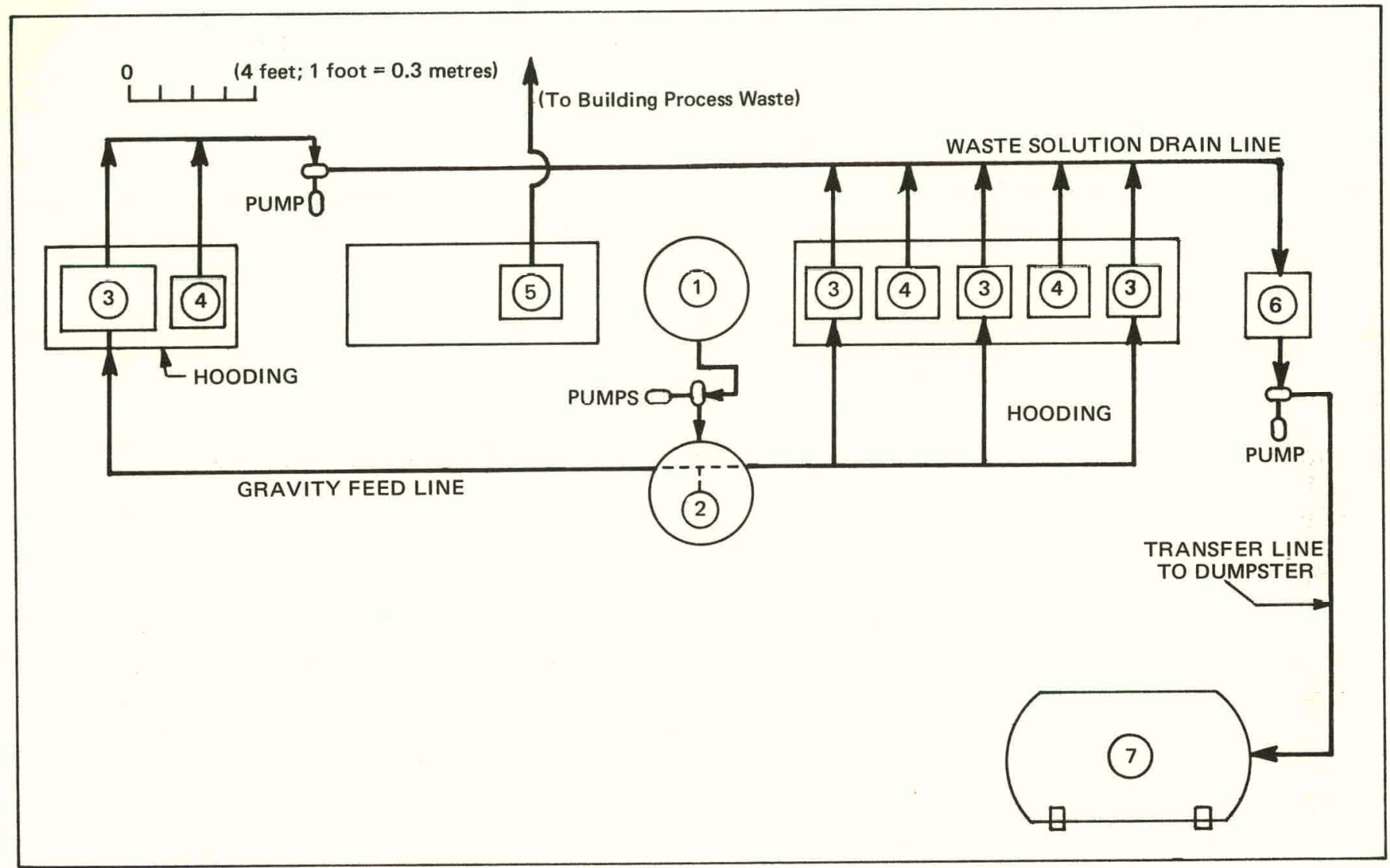

Legend

1. Solution Makeup Tank.

2. Elevated Storage Tank.

3. Chemical Milling Tanks.

4. Rinse Tanks.

5. Final Rinse Tank.

6. Waste Solution Collection Sump.

7. Portable Dumpster for Waste Solution.

FIGURE 3. Chemical Milling Process Equipment and Flow Diagram. 


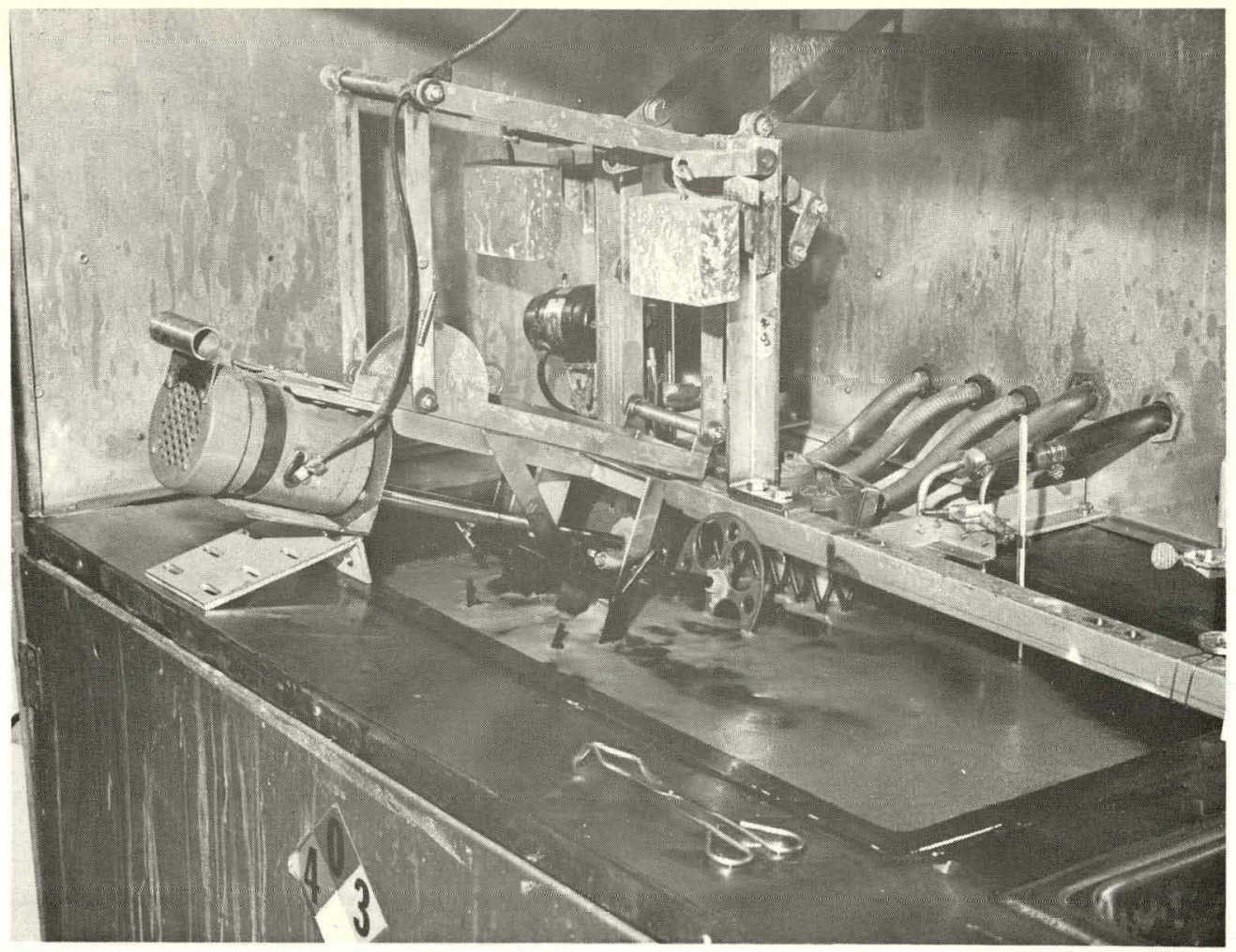

$17155-4$

FIGURE 4. Motorized Rotary Fixture in Operation.

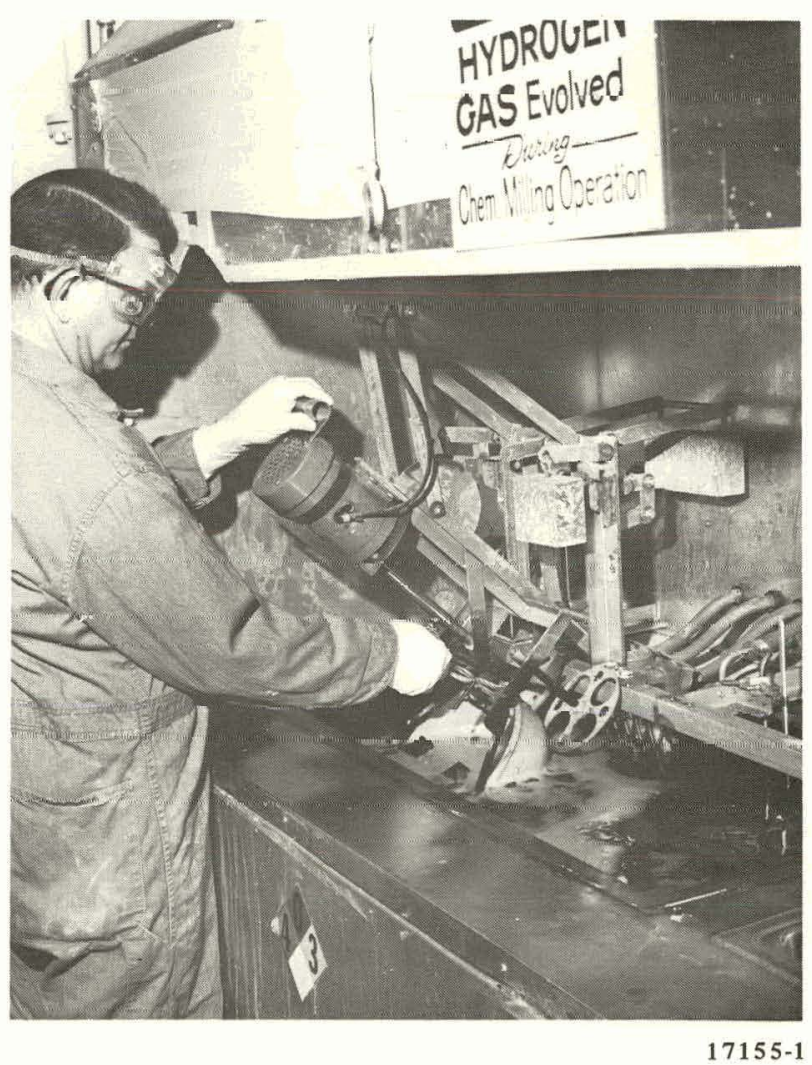

FIGURE 5. Motorized Rotary Fixturc. (Operator demonstrates raising and lowering for loading purposes.) 


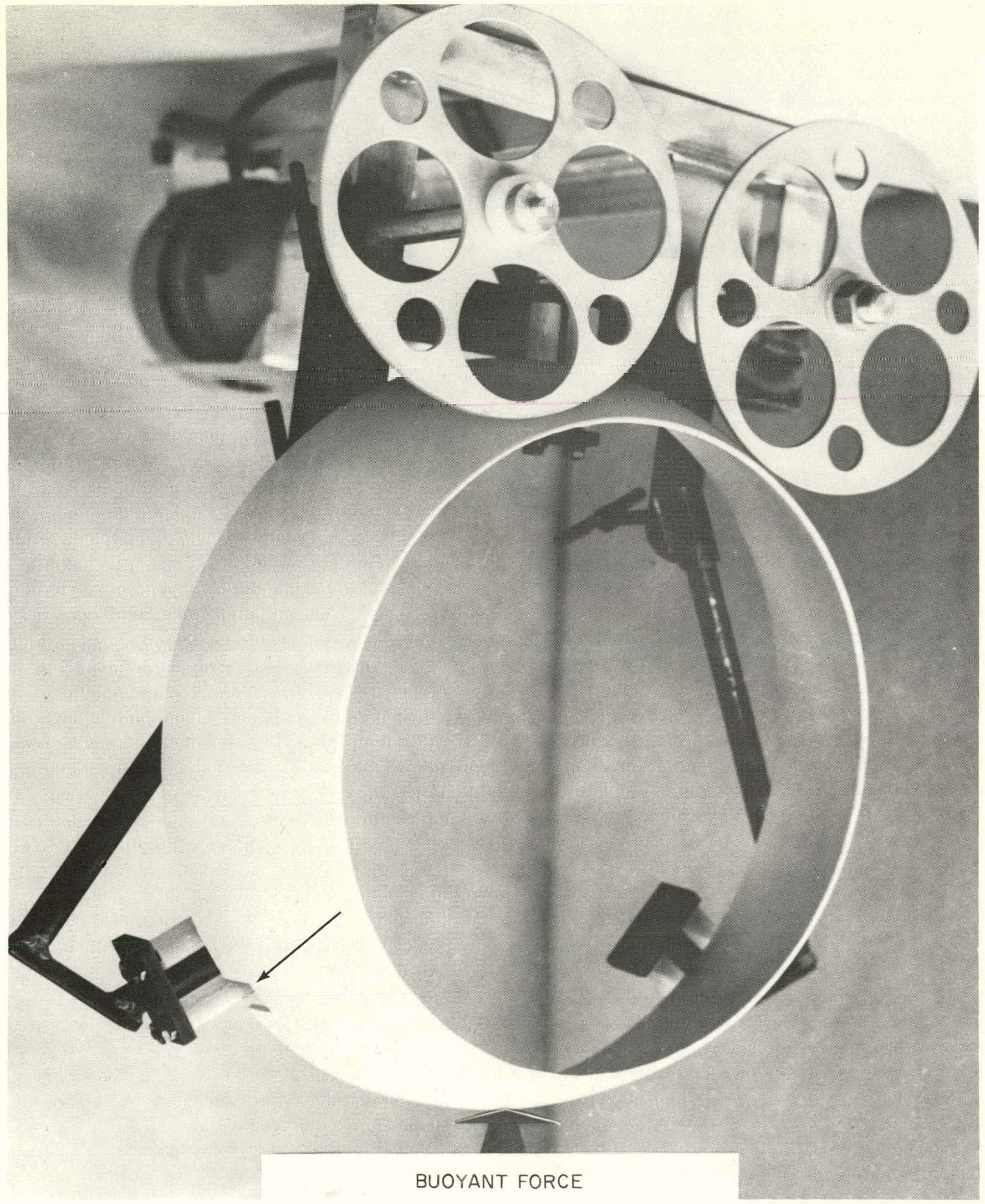

FIGURE 6. Rear View of Motorized Rotary Fixture. (Illustrates the double rollers and purpose. Note slotted ring part.) 


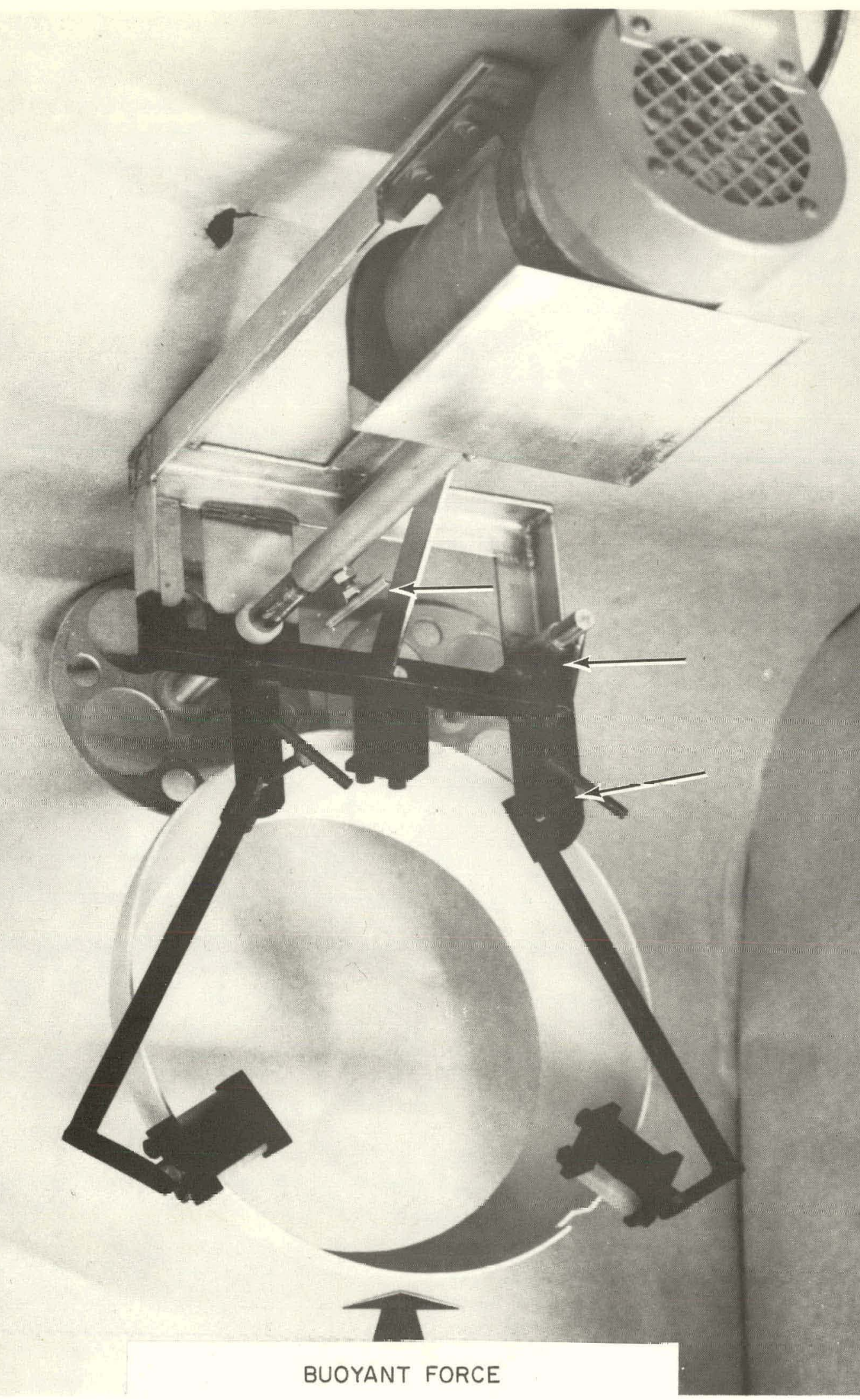

FIGURE 7. Front View of Motorized Rotary Fixture. [Illustrates adjustable arms and shafts. Note thumb screws (arrows) and slotted ring part.] 


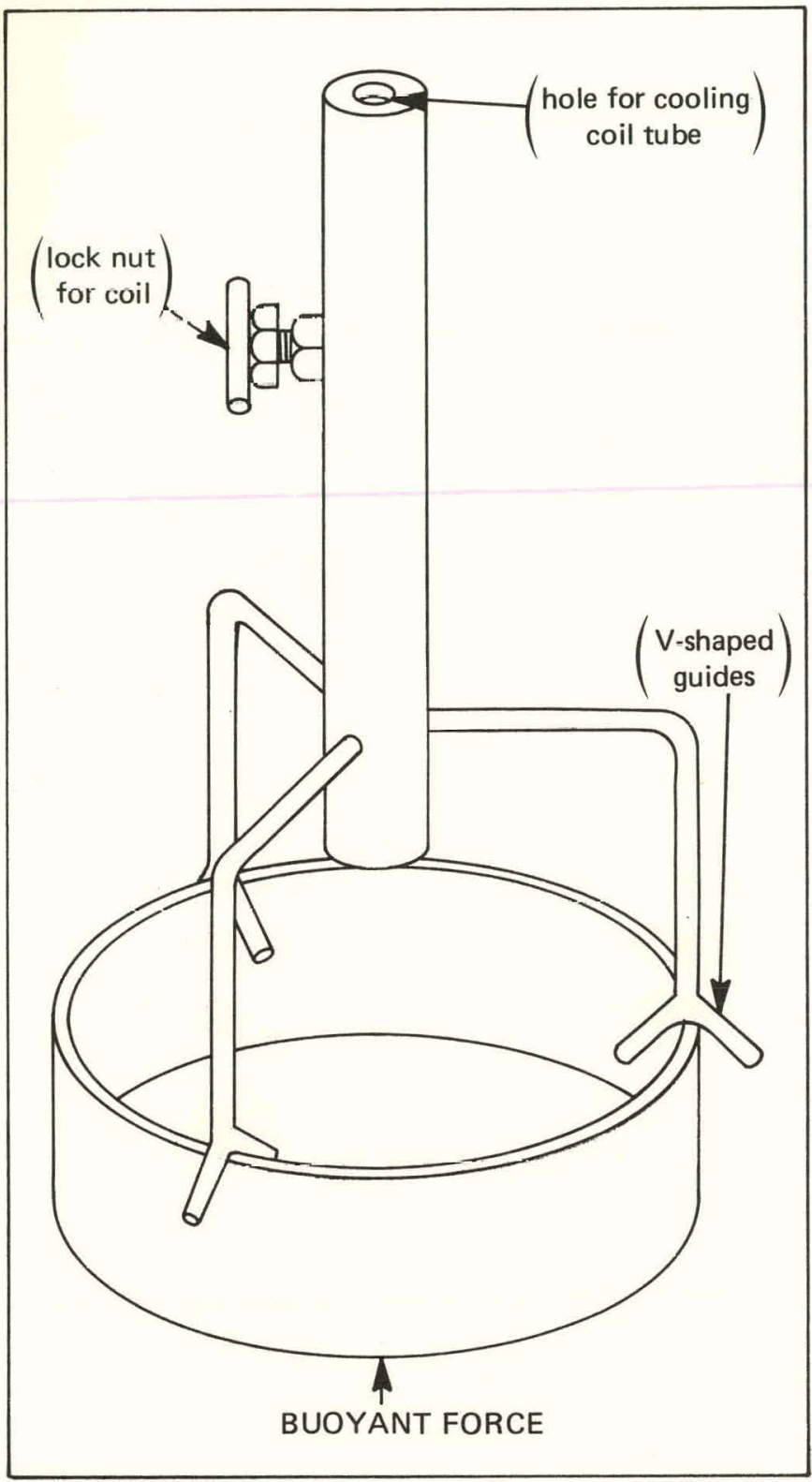

FIGURE 8. Stationary Beryllium Chemical-Milling Fixture.

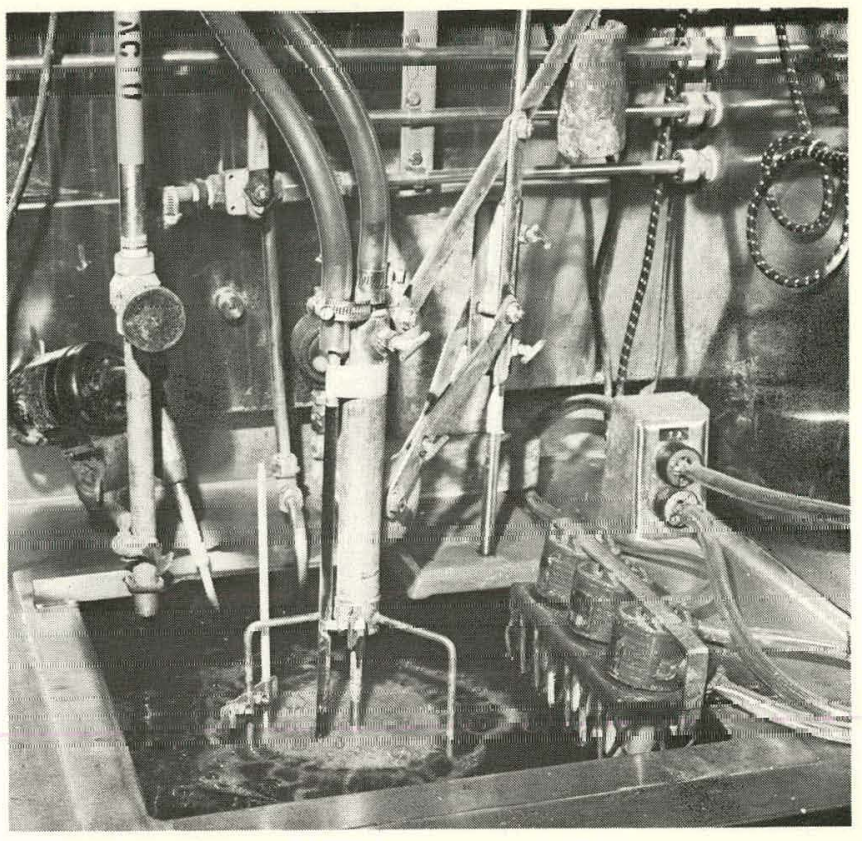

$17156-8$

FIGURE 9. Stationary Fixture in Operation.

FIGURE 10. Motorized Rotary Fixture. (Shown in UP position to demonstrate adjustment of roller arms.)

$15348-8$

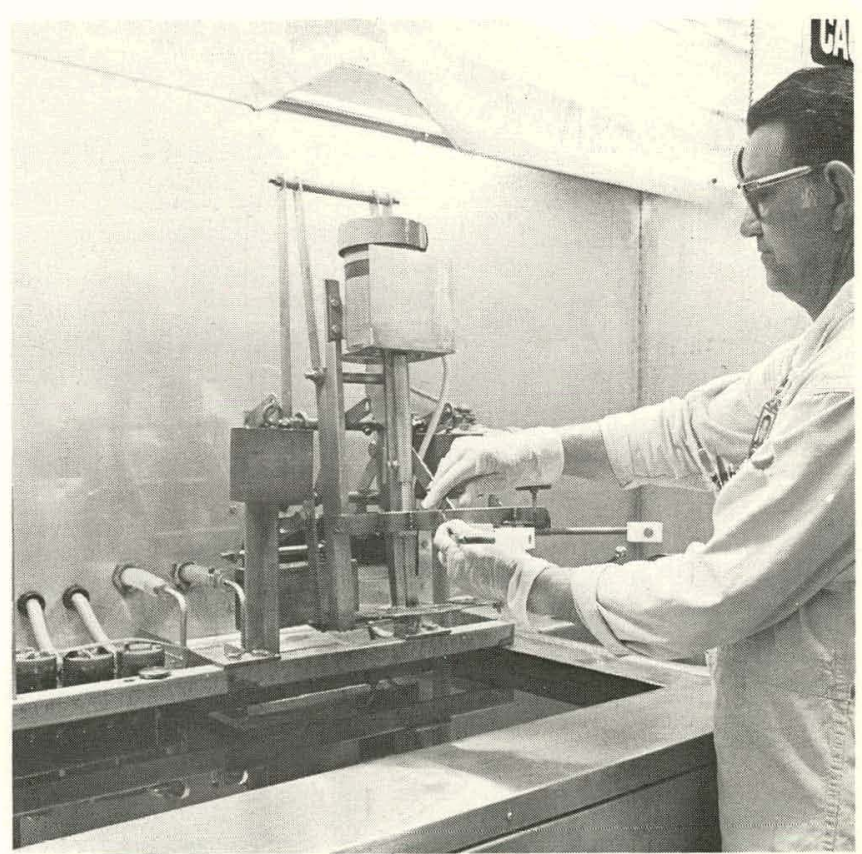




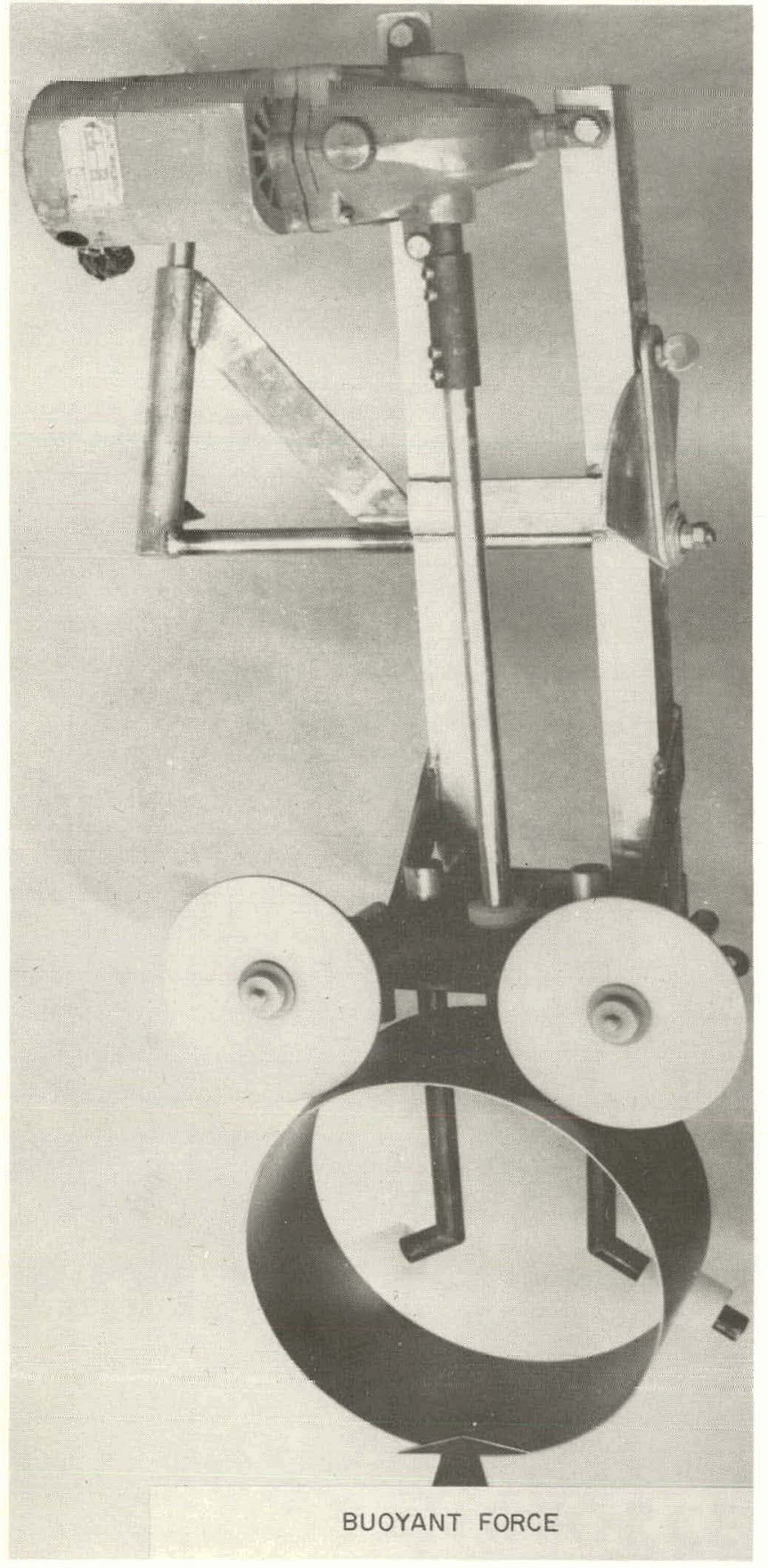

FIGURE 11. Rear View of Pilot Model Motorized Rotary Fixture.

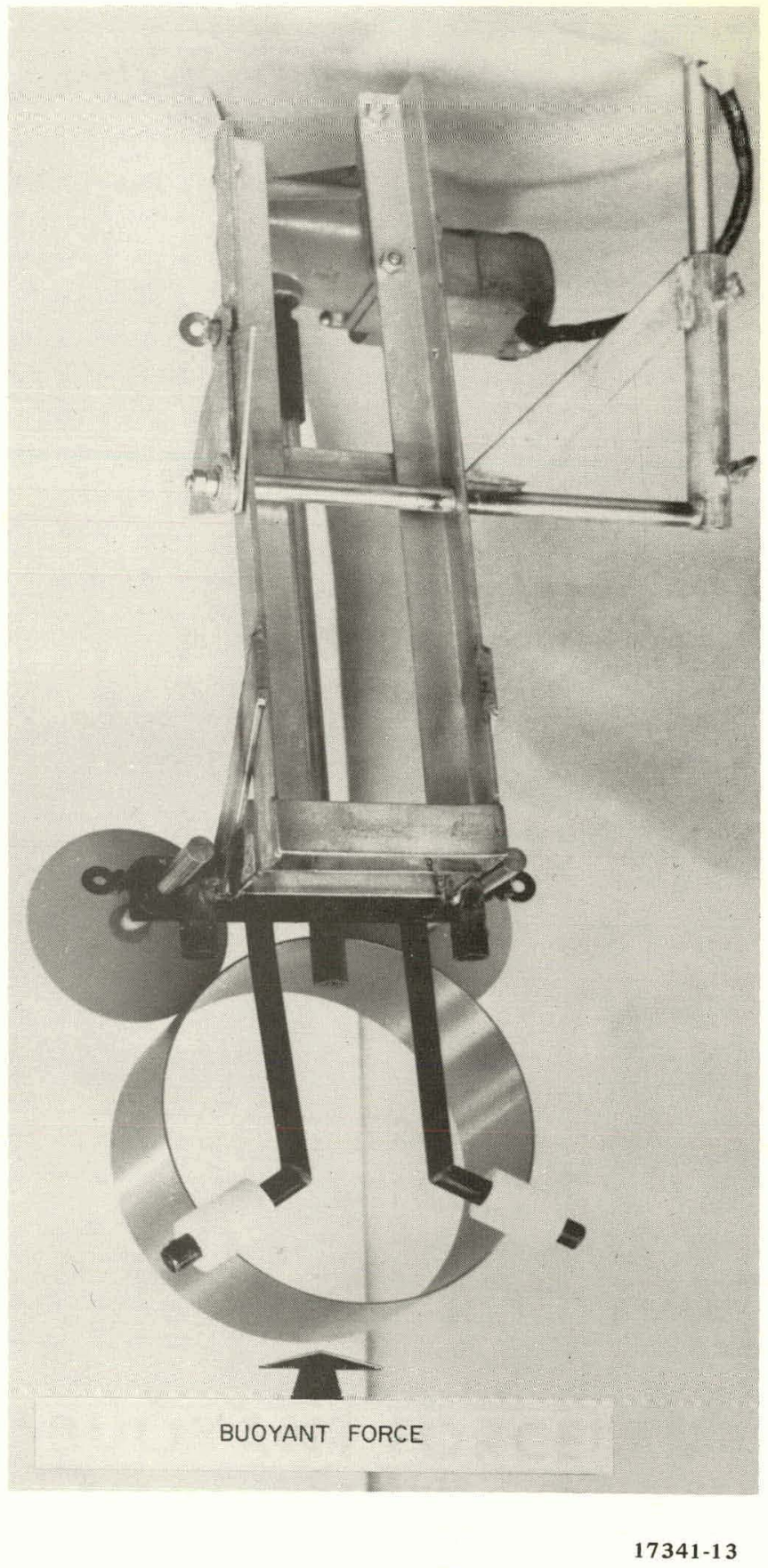

FIGURE 12. Front View of Pilot Model Motorized Rotary Fixture. 


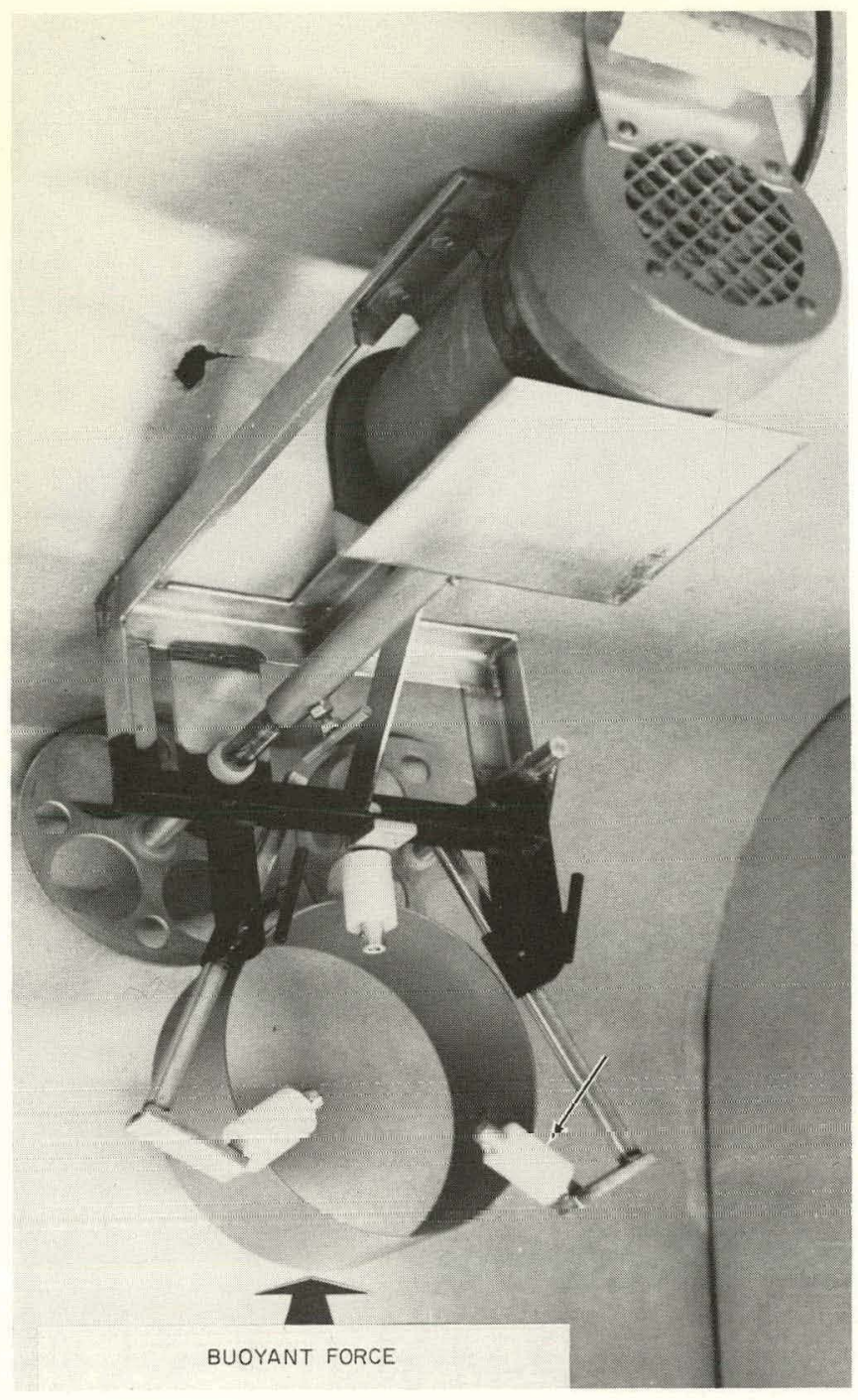

$17341-17$

FIgrJRE 13. First Production Múdel of Muluilized Rotary Fixture. (Shnwn are single rollers initially used.)
FIGURE 14. Modified Production Model of Motorized Rotary Fixture. (Shows plastic rider blocks initially used for the slotted ring.)

17341-14

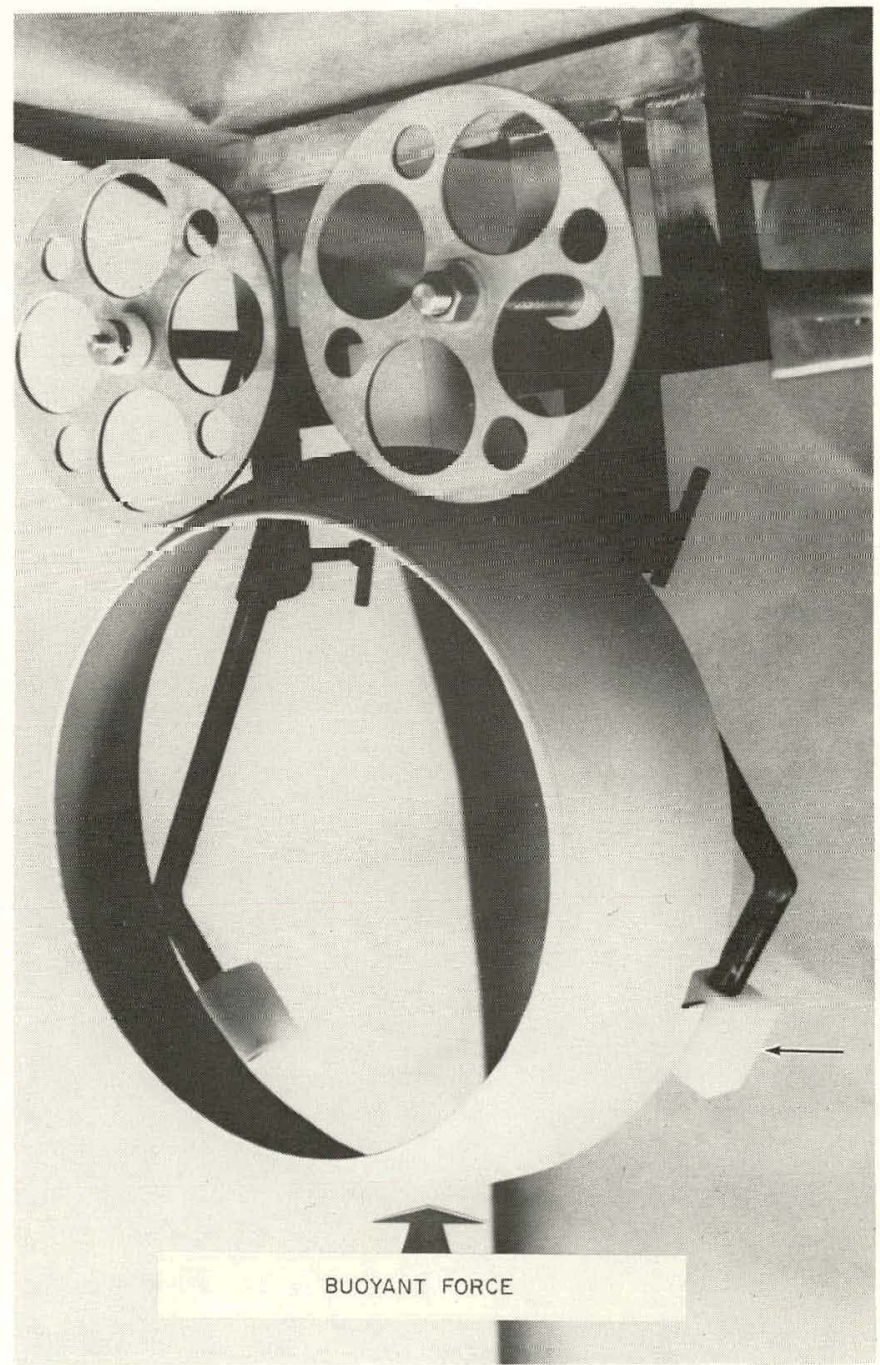




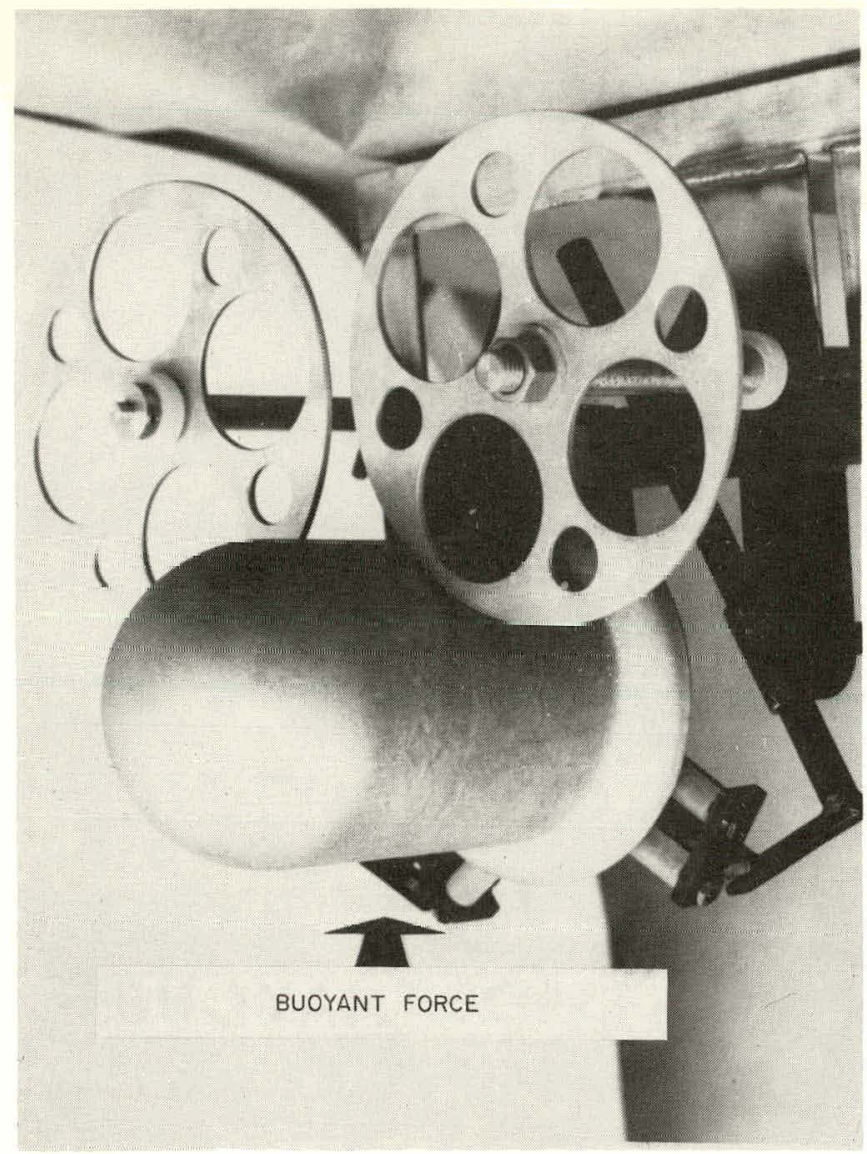

17341-20

FIGURE 15. First Production Model of Motorized Rotary Fixture. (Shown with a different part to illustrate versatility.)
FIGURE 16. Cooling Coil used with Stationary Fixturing for Internal Temperature Control.

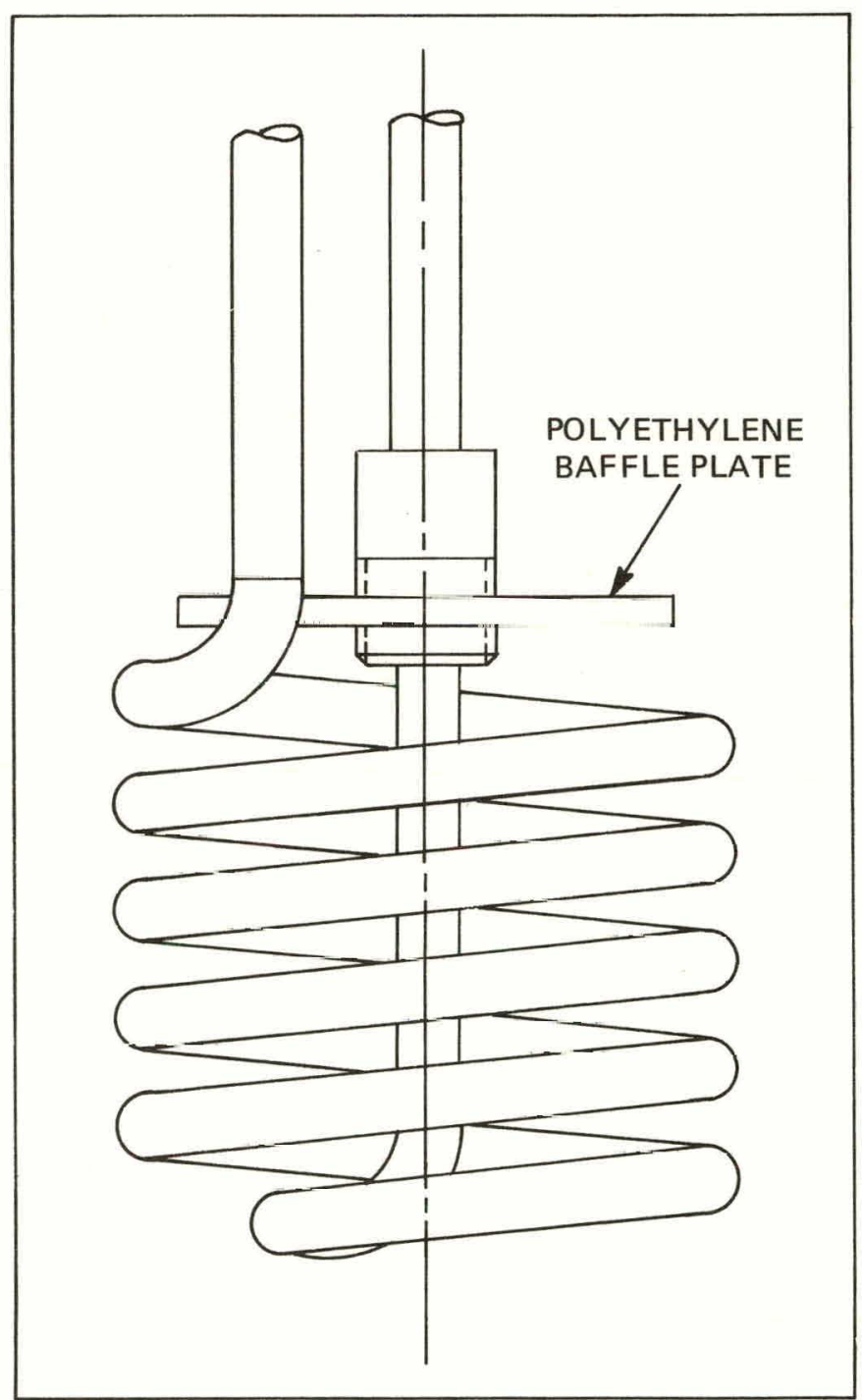

